HELMINTHOLOGIA, 56, 3: 183 - 195, 2019

\title{
Differential sensitivity of myeloid and lymphoid cell populations to apoptosis in peritoneal cavity of mice with model larval Mesocestoides vogae infection
}

\author{
T. MAČÁK KUBAŠKOVÁ1, D. MUDROŇOVÁ2, M. GERGEL'-ČECHOVÁ1, G. HRČKOVÁ1*

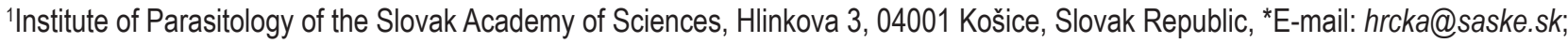 \\ ${ }^{2}$ Institute of Microbiology and Immunology, The University of Veterinary Medicine and Pharmacy, Komenského 57,
} 04181 Košice, Slovak Republic

Article info

Received May 8, 2019

Accepted May 22, 2019

\section{Summary}

The metacestode stage of the tapeworm Mesocestoides vogae ( $M$. vogae) has the ability of asexual growth in the peritoneal cavity of rodents and other intermediate hosts without restriction. Early immunological events have decisive role in the establishment of infection. In the present study we investigated the kinetic of myeloid and lymphoid cell populations and the proportions of cells undergoing apoptosis in peritoneal cavities of mice within the first month after oral infection with $M$. vogae larvae. Proportions of cell phenotypes and apoptotic cells were examined by flow cytometry and by microscopical analysis of cells following May/Grünwald staining and fluorescent stain Hoechst 33234 , respectively. Total numbers of peritoneal cells increased and their distribution changed towards accumulation of myelo-monocytic cell lineage in the account of reduced proportions of lymphoid cells. CD4+ T cell subpopulations were more abundant than CD8+ and their proportions elevated within two weeks post infection (p.i.) which was followed by a significant decline. Expression level of CD11c marker on myelo-monocytic cells revealed phenotype heterogeneity and proportions of cells with low and medium expression elevated from day 14 p.i. along with concurrent very low presence of CD11 chigh phenotype. Lymphoid cell population was highly resistant to apoptosis but elevated proportions of myeloid cells were in early/late stage of apoptosis. Apoptosis was detected in a higher number of adherent cells from day 14 p.i. onwards as evidenced by nuclear fluorescent staining. By contrast, cells adherent to larvae, mostly macrophages and eosinophils, did not have fragmented nuclei. Our data demonstrated that apoptosis did not account for diminished population of peritoneal lymphoid cells and substantial proportions of myeloid cells seem to be more susceptible to apoptotic turnover in peritoneal cavity of mice with ongoing $M$. vogae infection, suggesting their important role in the host-parasite interactions.

Keywords: Mesocestoides vogae larvae; mouse; peritoneal cells; apoptosis

\section{Introduction}

Mesocestoides vogae (syn. M. corti) infection in rodents has gained increasing acceptance as a model for proliferating larval cestode infections in immunological and chemotherapeutic studies. The metacestode stage, known as a tetrathyridium, multiplies asexually by anterio-posterior fission and budding mostly in the peritoneal cavities of mice or rats (Specht \& Voge, 1965). Larvae also invade the livers of the hosts, causing parenchymal destruction what ultimately leads to the initiation of fibrogenesis and enclosing larvae in the granulomatous fibrous capsules (Specht \& Widmer, 1972; Hrčková et al., 2010). After oral infection of highly

\footnotetext{
$\overline{\text { * }- \text { corresponding author }}$
} 
susceptible ICR strain of mice, larvae appear in the peritoneal cavity as early as on day 3 post infection (p.i.), triggering early pro-inflammatory immune response with larvicidal potential (Vendelova et al., 2015). Laboratory mice seem to be very suitable animals for establishment of the infection by both oral and intraperitoneal route, what however, influences the kinetics of immune response in the peritoneal cavity (PerC) (White el al., 1982). It was showed that the local immune response in PerC of ICR strain, examined on mRNA levels, is characterized by minimal IFN- $\gamma$ production up to day 7 p.i., transient IL-4 elevation, followed by a dominant IL-10 production. Beside recruited eosinophils, parasite-elicited monocytes/macrophages attained the characteristic of alternatively activated macrophages (which also been called M2 myeloid cells (Martinez et al., 2009), based on the high expression of mRNA for Fizz-1, YM1 and Arg-1proteins (Vendelova et al., 2015; Horsnell \& Brombacher, 2010).

Differentiation of M2 cells is induced by IL4/IL-13 cytokines through the IL-4R $\alpha$ (Brombacher et al., 2009) that also favor T helper (Th) 2 cell polarization. Intraperitoneal injection of live and in lesser extent heat-killed $M$. corti larvae, elicited a significant recruitment of CD11c+ cells up to day 7 p.i. (Vendelova et al., 2016b).

Resident peritoneal cells in various strains of mice also contain $B$ and T lymphocytes (Composto et al., 2011). Lymphocytes were observed in low numbers in PerC of C57BL/6 strain of mice on cytospin preparations within onset of $M$. corti infection $\left(\mathrm{O}^{\prime} \mathrm{Con}\right.$ nel et al., 2009). A key feature of helminth infections is an early induction of strong Th2-biased immune response in their hosts. After stimulation, CD4+T cells differentiate to distinct subsets characterized by their functions and cytokine profiles (Th1 vs. Th2 cells). Increasing number of studies report that excreted/secreted products from helminths play the crucial role in promoting Th2 response and inducing immunosuppression in the chronic stage of infections (Rodriguez-Sosa; 2002; Vuitton \& Gottstein, 2010; Vendelova et al., 2016a; Vendelova et al., 2016b). Multiple types of immunosuppressive cells operate in the immune system, including CD4+Foxp3+ regulatory T cells, B cells and macrophages which dampen Th2 immunity towards $T$ regulatory type (Maizels et al., 2012, Gordon \& Martinez, 2010). In avoiding severe peritoneal inflammation and liver pathology with the fatal consequences for the hosts, fast growing $M$. vogae infection has to promote early down-regulation of Th2 type of immunity (Vendelova et al., 2015). IL-4, a canonical Th2 cytokine involved also in liver fibrotic response to invading tetrathyridia, was shown to be the essential cytokine in the regulation of $M$. corti infection in C57BL/6 mice (Rawat et al., 2003) and its absence resulted in augmented proliferation of larvae. Numerous studies showed that immune response to flatworm infections is regulated specifically in different periods of infection and developmental stages by parasite-derived molecules (Maizels, 2009; Voehringer et al., 2004; Vuitton \& Gottstein, 2010) employing also programmed cell death - apoptosis (Nono et al., 2012; Spotin et al., 2012; Zepeda et al., 2010). Apoptotic processes can be divided into extrinsic and intrinsic pathways. The extrin- sic pathway involves the members of TNF- $a$ and TNF- $a$ receptor family of proteins and down-stream activation of the caspases cascade. The key feature of the intrinsic apoptotic pathway is the breakdown in the integrity of the mitochondrial outer membrane. Early apoptotic events include exposure of phosphatidylserine on the cell surface, whereas morphological changes associated with the later stage is nuclear and chromosomal fragmentation, chromatin condensation, cell shrinkage followed by the formation of apoptotic bodies (Wyllie, 1997). Thus the selective elimination of a certain cell type might be a way by which flatworms are able to maintain the suitable immunological settings and reduced harmful pathology.

The aim of present study was to investigate the kinetics of cellular immune response in peritoneal cavity of ICR strain of mice infected with proliferating tetrathyridia of $M$. vogae. We also assessed the kinetics of apoptosis in lymphoid and myeloid cell populations as well as in cells adherent to the larval surface within the first month of infection.

\section{Material and Methods}

Parasites and infection

Infection with tetrathyridia of $M$. vogae is maintained by intraperitoneal passage through ICR-strain of mice at the animal facilities of Institute of Parasitology of the Slovak Academy of Sciences under pathogen-free conditions. Prior to initiation of the experiment, tetrathyridia were recovered from the peritoneal cavity of a mouse with long-term infection (3 months). In the experiment, male mice of the same strain aged 8weeks were orally inoculated with $65 \pm 2$ tetrathyridia in $0.2 \mathrm{ml}$ of sterile PBS by the oral gavage.

\section{Peritoneal exudate cells}

Mice were sacrificed by cervical dislocation and peritoneal exudates cells (PEC) were collected by washing the peritoneal cavity with RPMI medium (Biochrom-Merck, Germany) containing $2 \mathrm{mM}$ of stable glutamine and supplemented with $10 \%$ heat-inactivated bovine fetal serum (Biochrom-Merck, Germany), 100U/ml penicillin, $100 \mu \mathrm{g} / \mathrm{ml}$ streptomycin, $10 \mu \mathrm{g} / \mathrm{ml}$ gentamicin and $2.5 \mu \mathrm{g} / \mathrm{ml}$ amphotericin B (complete medium, CM) (all from Sigma-Aldrich, St. Louis, USA). The PEC suspension was washed with LPS-free Dulbecco phosphate buffered saline (DPBS), re-suspended in CM and counted. Total cell numbers obtained from PC of each mouse was enumerated. For preparation of cell smears of PEC, approximately $0.1 \times 10^{6}$ cells from PerC of infected mice were re-suspended in DPBS, placed on glass slides and fixed in $70 \%$ methanol. Viability of the cells was more than $95 \%$ as determined by trypan blue exclusion. Cell suspensions were used for phenotypic analysis and level of apoptosis performed by flow cytometry. In addition, part of cell suspensions were left to adhere onto glass slides which were placed into quadriPERM ${ }^{\circledR}$ chambers (Sarstedt, Germany) for $3 \mathrm{~h}$ at $37^{\circ} \mathrm{C}, 5 \% \mathrm{CO}_{2}$ in $\mathrm{CM}$ allowing cells to adherence. After washing, the non-adherent cells were collected and used to 
prepare cell smears. Both cell preparations were used to assess apoptosis by morphological criteria.

\section{Isolation of cells attached to larval surface}

To investigate whether PEC are adhered to the larval surface, larvae isolated from peritoneal cavities of individual mice were properly washed several times in PBS, placed into complete medium and incubated for $2 \mathrm{~h}$ at $37{ }^{\circ} \mathrm{C}$ with shaking. Medium was collected, centrifuged and cell pellets were isolated. Then larval adherent cells isolated on indicated time points after infection were pooled and cell smears were prepared. Slides were stained with either May- Grünwald/Giemsa solutions or Hoechst 33342 (ThermoFisher Scientific, USA) for morphological detection of apoptotic cells.

\section{Flow cytometry}

Single-cell suspension of PEC isolated from intact and infected mice were prepared as described above. Cells were re-suspended in $\mathrm{CM}\left(0.5 \times 10^{6} \mathrm{cell} / \mathrm{s} / 100 \mathrm{\mu l}\right)$ and stained with anti-mouse monoclonal antibodies: anti-CD4-FITC (clone GK1.5), anti-CD8-PE (clone 53-6.7), anti CD 11C (PerCP Cyanine 5.5). Isotype-matched monoclonal antibodies (isotype $\lg \mathrm{G} 2 \mathrm{~b}$ and isotype $\lg \mathrm{G} 2 \mathrm{a}$ and $\lg M$ ) were used as controls (all antibodies were from eBioscience, Germany). Cell samples were incubated with antibodies in the dark for 30 min at room temperature and washed twice with FACS buffer. Finally, cells were re-suspended in 100 $\mu$ of FACS buffer. Phenotypic analysis was performed on a FACS Canto (Becton Dickinson Biosciences, USA) and data were analyzed using FACS Diva software.

\section{Annexin V/propidium iodide apoptosis assay}

Cell suspensions isolated from peritoneal cavities of mice were also used to study stages of apoptotic process in addition of phenotypic analysis. Cells were re-suspended in CM $\left(1 \times 10^{6}\right.$ cells/100 $\mathrm{ll}$ ) and placed to ice until the staining. Apoptosis was detected with BD Pharmingen Annexin V-FITC Apoptosis Detection Kit (APO Alert Annexin V, Clon Tech, California, USA) according to manufacturer's instructions. Briefly, treated cells were centrifuged for $10 \mathrm{~min}$ at $1500 \mathrm{rpm}$ to remove CM. Later, the cells were washed and resuspended in $200 \mu$ l of the binding buffer. Apoptotic cells were detected after their staining with $5 \mu$ of Annexin $V$ and $10 \mu \mathrm{l}$ of propidium iodide solution. Cells were then incubated at room temperature in the dark for $15 \mathrm{~min}$. Analysis was performed by flow cytometry.

\section{May-Grünwald staining of cell smears}

Slides with cell smears and adherent cells were stained with May-Grünwald/ Giemsa solutions according to the standard procedure. The stained cells were then observed under the light microscope (Olympus, Prague, Czech Republic) and analysis of cell types was done at $1000 \mathrm{x}$ magnification.
Detection of apoptosis on cell smears

Morphological changes of cells undergoing late stage of apoptosis can be detected by condensed chromatic and/or fragmented nuclei after staining of cell nuclei with DNA-specific dye Hoechst 33342 (ThermoFisher Scientific, USA). The final dye concentration was $2 \mu \mathrm{g} / \mathrm{ml}$ in PBS. Cell smears were fixed with $4 \%$ formaldehyde for $10 \mathrm{~min}$ at room temperature and washed with PBS. Cells were then incubated with Hoechst dye for 20 min at room temperature in dark. The stained cells were observed under a fluorescence microscope (Leica DM4000 B, Germany) and cells with above mentioned morphological changes were counted. At least 200 total cells were counted on slides with cells isolated from 3 mice for each time-point. Finally proportions ( \%) were calculated and are expressed as mean \pm SD.

\section{Statistical analysis}

Data obtained from individual analyses for indicated number of samples were finally calculated as mean $\pm \mathrm{SD}$. Results were analyzed either by one-way ANOVA followed by Tukey's post- hoc test. In the grouped analyses two-way ANOVA and Sidak's posthoc test were applied. Data were evaluated using GraphPad Prism (version 7) (GraphPad Software, Inc., San Diego, CA, USA) and differences were regarded as significant when $p<0.05$.

\section{Ethical Approval and/or Informed Consent}

The experiment was carried out according to the guidelines for the care and use of experimental animals No. 289/2003 and approved by State Veterinary and Food Administration of the Slovak Republic under project No. 3871/15-221d.

\section{Results}

Larval proliferation is associated with accumulation of myeloid cell types in the peritoneal cavity

Metacestodes of $M$. vogae extensively reproduce within the mouse liver and PerC (Specht and Voge, 1965; Specht and Widmer, 1972) and the first larvae appeared in PerC already on day 3 p.i. (personal observations). Flow cytometry analysis revealed that with progressing infection distribution of cell types has been dramatically changed towards accumulation of myelo-monocytic cell lineage in the account of reduced proportions of lymphoid cell types (Fig. 1A, C). We showed that the total cell numbers in PerC gradually increased as the infection progressed and reached 64.8 $\pm 18.1 \times 10^{6}$ cells on day 28 p.i. (Fig. 1B). Analysis of stained cell smears confirmed that the proportions of lymphocytes gradually decreased and recruited myelo-monocytic cell fraction comprised mixture of macrophages cells having different staining pattern and size, multinucleated giant cells as well as eosinophils, and in the lesser extent, neutrophils (Fig. 1D). 
Proportions of CD4 +/CD8+ T lymphocytes are differentially regulated during onset of infection

The general feature during establishment of tissue-dwelling helminth infections is proliferation of parasite-specific $T$ cells which display highly polarized Th2 cytokine profiles. We next analysed the proportions of $\mathrm{T}$ cell subpopulations by flow cytometry. As depicted in Fig. 2, CD4+ cells were more abundant population than CD8+ in PerC of healthy ICR mice. Their proportions elevated within two weeks p.i. what was followed by a significant decline. Proportions of CD8+ cells did not change significantly up to day
28 p.i., although total lymphoid population increased (not shown) as is depicted from a massive accumulation of inflammatory cells. We assume that the composition of lymphoid population has been changed from day 14 p.i. towards elevated numbers of other lymphoid cells, probably B cells and NK cells.

Differential expression level of CD11c marker on myeloid cells during onset of infection

CD11c cell surface molecule is an important molecule in regulating immune responses and its expression depends on cell type
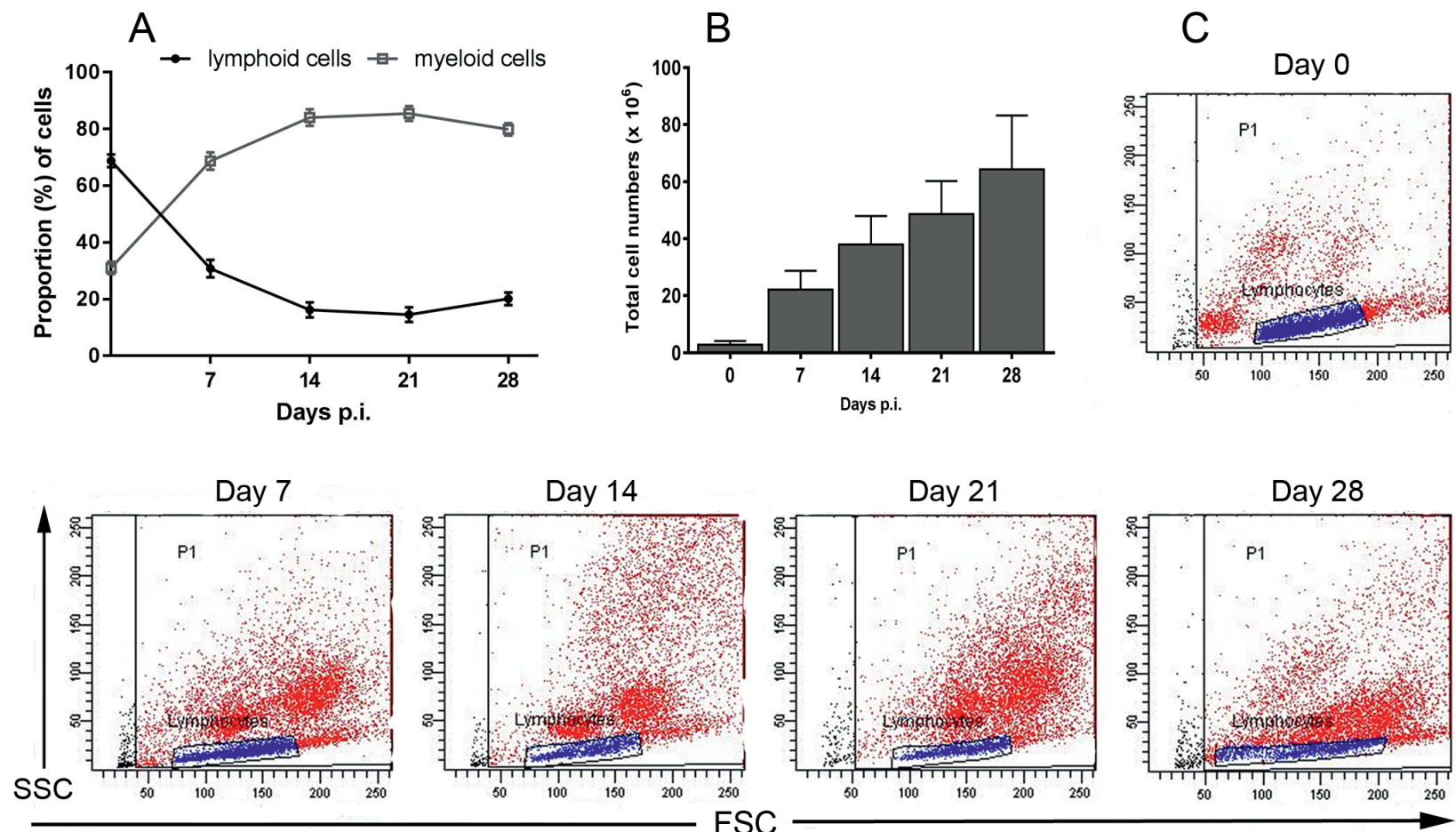

D

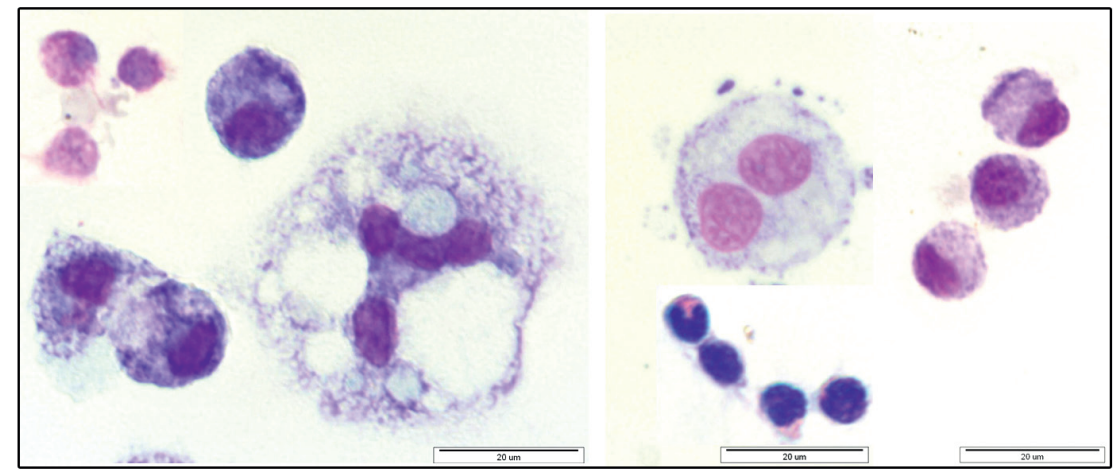

Fig. 1. Mesocestoides vogae infection is associated with accumulation of myeloid cell in the peritoneal cavity of infected mice. ICR mice were infected orally with $65 \pm 2$ tetrathyridia. At the indicated time points, proportions of lymphoid and myeloid cells $(A)$ and total cell numbers (B) in the peritoneal cavities of healthy and infected mice were assessed by flow cytometry. Data are present as the means \pm SD. (C) Representative dot plot shows FSC and SSC gating of total peritoneal cells. (D) Representative images of May-Grünwald/Giemsa-stained cell smears prepared from peritoneal fluid of infected mice. The images show populations of myeloid cells including giant cell, granulocytes and lymphoid cells. Original magnification $=1000 \mathrm{x}$; Scale bar: $=20 \mu \mathrm{m}$. 
and state of activation (Singh-Jasuja et al., 2013). In the present study myelo-monocytic cells from PerC of intact and infected mice were assessed for the expression level of this marker showing surface phenotype heterogeneity after gating on cells designated

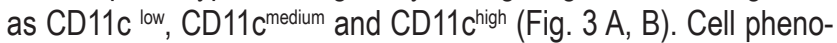
type $\mathrm{CD} 11 \mathrm{C}^{\text {low }}$ was dominant in intact mice and in infected mice up to day 7 p.i. During this period $C D 11 c^{\text {medium }}$ cells formed smaller population, what was enlarged by day 28 p.i. representing 40.1 $\pm 4.0 \%$. High expression of CD11c is considered to be more restricted to mature dendritic cells (Lai et al., 1998), but in our study CD11 $c^{\text {high }}$ phenotype did not form discrete cell population, neither in intact peritoneal cells, nor in peritoneal exudate cells from infected mice, and represented very low population through examined period. Moderate elevation of this phenotype was detected on day 14 p.i. $(16.8 \pm 1.1 \%)$.

Myeloid cells are more susceptible to apoptosis than lymphoid cells

Helminth parasites evolved several strategies in inducing immunosuppression and increasing body of evidence propose apoptosis as an effective mechanism in reducing viability of a certain cell populations or their complete removal to avoid immune attack (Solano et al., 2006, Serradell et al., 2007, Zepeda et al., 2010).
To investigate which cell type is more resistant to apoptosis, PEC were stained with annexin $V$ and propidium iodide. Gating strategy involved separate analysis of lymphoid and myeloid cell populations (Fig. 4A) followed by discrimination of three populations: live cells, cells in the early stage of apoptosis and cells in late stage including dead cells. Interestingly, nearly all lymphoid cells retained their full viability through the examined period and dead cells were not detected (Fig. 4 B). In contrast, phenotypically heterogeneous myeloid population underwent programmed cell death at a various levels (Fig. 4C). In PerC of intact mice more than $80 \%$ of these cells were live and small proportions were in the early and late apoptosis, respectively. With progressing infection proportions of live cells diminished, whereas percentage of early apoptotic cells increased, most notably from day 14 p.i. From this day, elevated number of cells in late stage of apoptosis was recorded. As shown by images from cell distribution analyses based on size (FSC) and granularity (SSC) (Fig. 4D upper panel), live cells were co-localized with macrophages and early apoptotic cells were situated at positions where granulocytes occur, probably eosinophils or other granular cells. Late apoptotic cells formed mixed population of giant cells and large granular cells, which were stained intensively with acidic stains giving light blue/pink appearance on the cell smears (see Fig.1D).

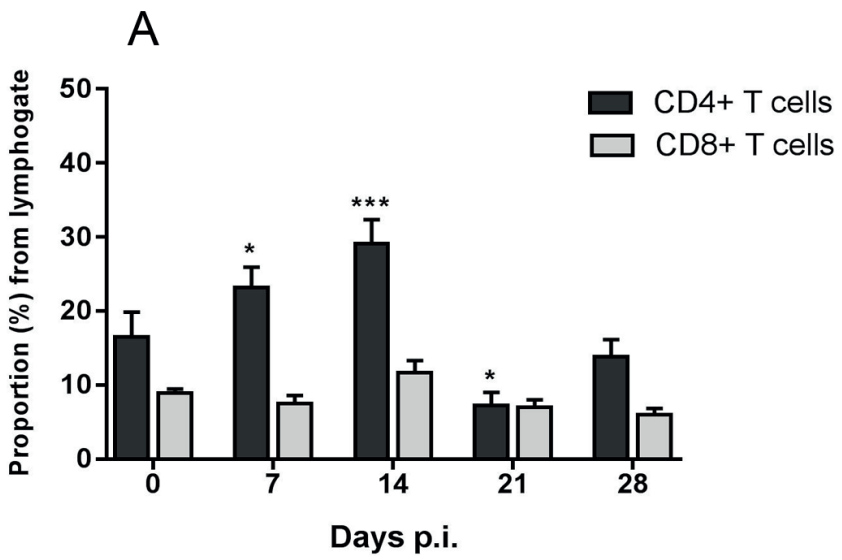

B Day 0

Day 7

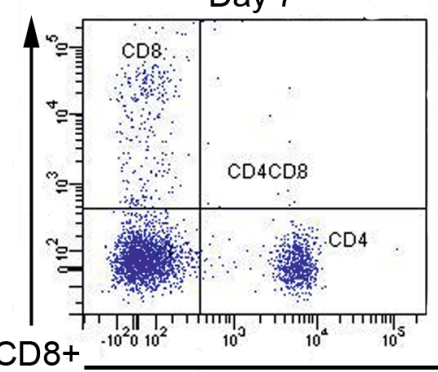

Day 14

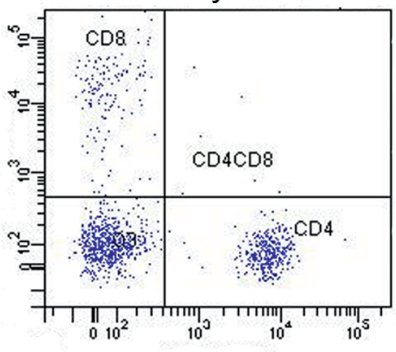

Day 21

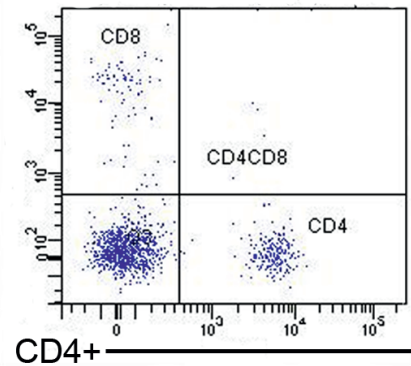

Day 28

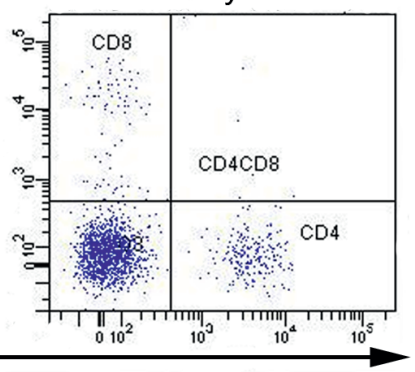

Fig. 2. Proportions of CD4 +/CD8+ T lymphocytes in peritoneal cavity are differentially regulated during onset of Mesocestoides vogae infection. (A) Peritoneal cells isolated from healthy and infected mice analyzed for CD4 and CD8 from lymphogate by flow cytometry. Data are expressed as the means \pm SD. Values significantly different from healthy mice are indicated as: ${ }^{*} p<0.05,{ }^{* * *} p<0.001$. Representative dot plots (lower panel) show the expression of CD4/CD8 (B) on peritoneal cells. 
Adherent myeloid cells are more sensitive to late apoptosis than non-adherent cells

Cells which enter apoptotic process can be distinguished from healthy ones morphologically after visualisation of their nuclei with fluorescent nuclear dye. Adherence to plastic or glass surface is believed to be property of monocytes/macrophages and some subpopulation of dendritic cells. To investigate apoptosis morphologically, we prepared adherent and non-adherent cell fractions on slides, which were stained either with May-Grünwald/Giemsa solutions and or with fluorescent dye Hoechst 33342. Cells with condensed chromatin were considered to be in the early stage, whereas cells with fragmented nuclei were apparently in late stage. Fig. $5 \mathrm{~A}$ shows proportions of late stage apoptotic cells detected for adherent and non-adherent cells, using fluorescent microscopy. Adherent cells comprised majority of cells with monocyte/macrophage appearance but also smaller cells, probably granulocytes (Fig. 5C, arrows). In agreement with results obtained by flow cytometry, the percentage of adherent apoptotic cells increased by day 7 p.i. and after a drop on day 14 p.i., their proportions gradually increased up to day 28 p.i. (Fig. 5A, B). Only minor population of non-adherent cells, comprising mostly lymphocytes and small proportions of granulocytes, underwent late apoptosis and peak was found on day 21 p.i. (Fig. $5 \mathrm{~A}, \mathrm{D}$ ).
Mixed populations of myeloid cells were adhered to larval surface We next tested whether myeloid cells from infected mice can adhere to larval surface and if they undergo apoptosis. We first analysed cell smears after May-Grünwald/Giemsa staining and counted individual cell type. We detected two populations of macrophages based on affinity to basophilic and acidophilic stains and these cells were dominant cells adhered on the larval tegument (Fig. 6 A, B). The presence of granulocytes, mainly eosinophils, was gradually augmented within the first month of infection. Lymphocytes were absent and other cell types having bigger nuclei and several cytoplasmic extensions were found in lower numbers. Fluorescent staining of nuclei did not show cells in late stage of apoptosis, however small proportions of cells appeared to have condensed chromatin (Fig. 6 D, arrowheads).

\section{Discussion}

Murine peritoneal cavity has served immunologists as the site to study inflammation in vivo and as the source of activated (elicited) myeloid cells for in vitro studies. It is also interesting anatomical niche to study host-parasite interactions during infection with larval stage of cestodes, for example metacestodes of M. corti (syn. M. vogae) (Jenkins et al., 1991; Hrčková \& Velebný, 1997; Hrčková et
A

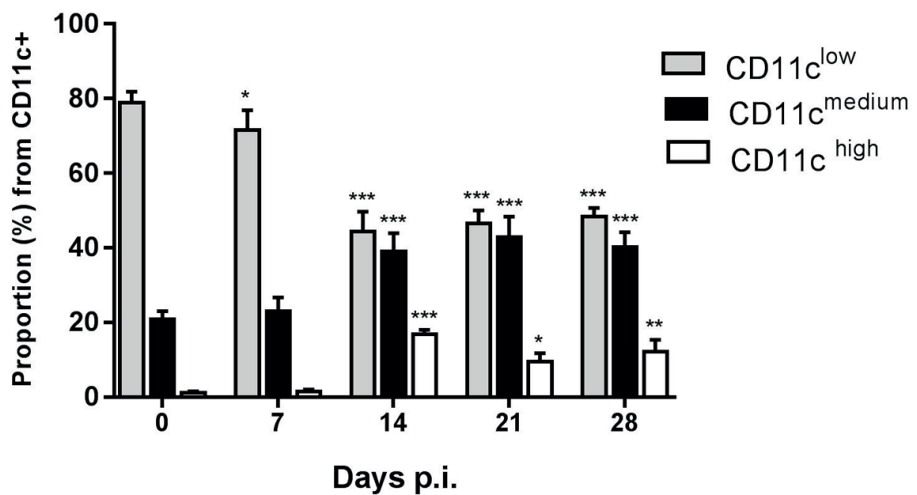

Day 7

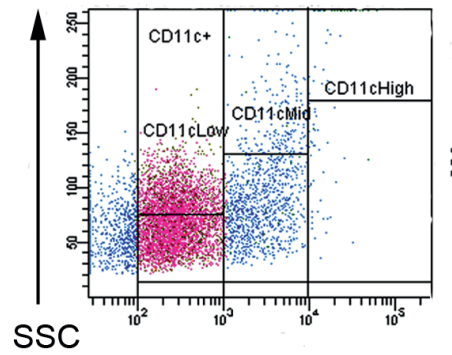

Day 14

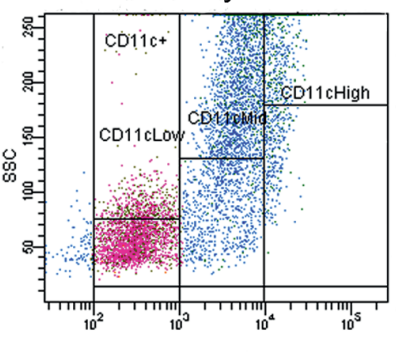

B

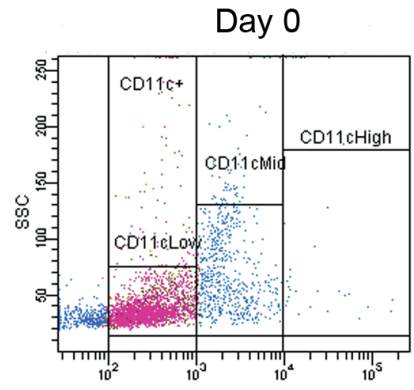

Day 21

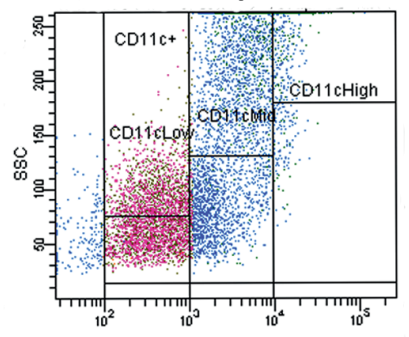

Day 28

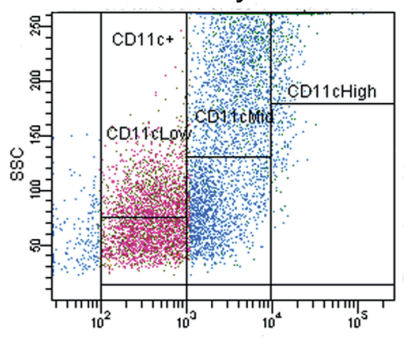

CD11c

Fig. 3. Myeloid peritoneal cells differentially express CD11c marker during Mesocestoides vogae infection. (A) Peritoneal cells isolated from healthy and infected mice analyzed for CD11c from total cells by flow cytometry. Data are expressed as the means \pm SD. Values significantly different from healthy mice are indicated as: ${ }^{*} p<$ $0.05,{ }^{* *} p<0.01,{ }^{* * *} p<0.001$. Representative dot plots (lower panel) show the expression of CD11c (B) on peritoneal cells. 
Lymphoid cells

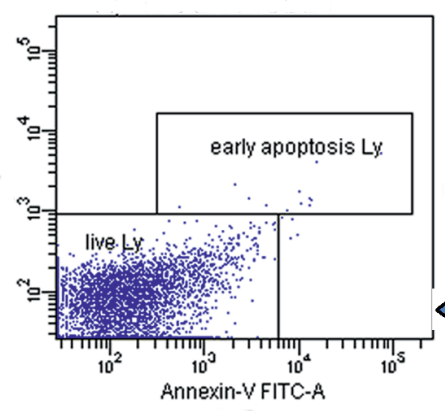

B

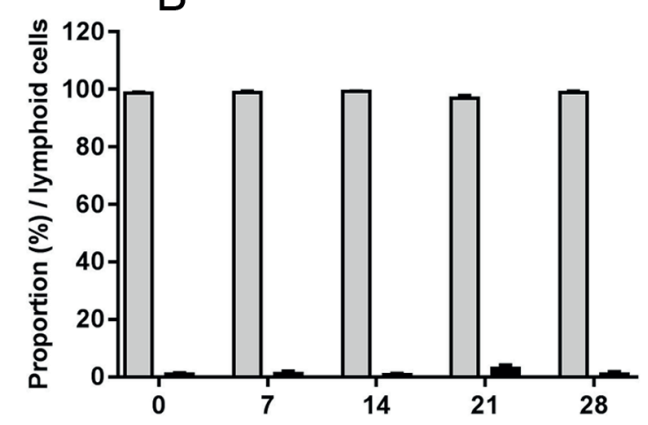

\section{Days p.i.}
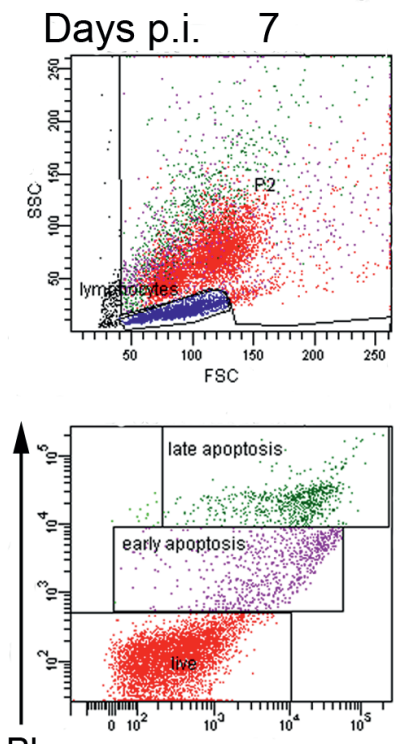

$\mathrm{PI}$
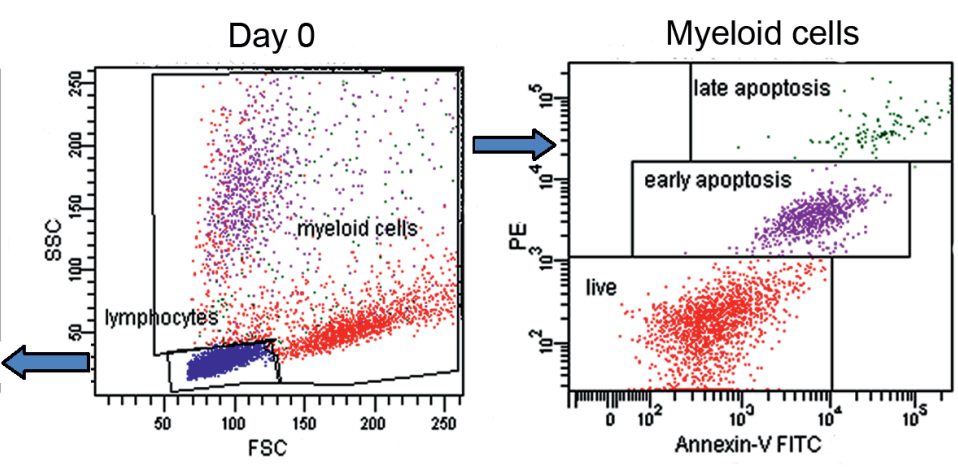

C

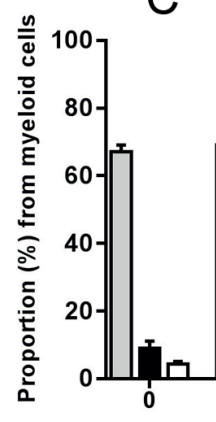

$\square$ live

- early apoptosis

$\square$ late apoptosis/ dead
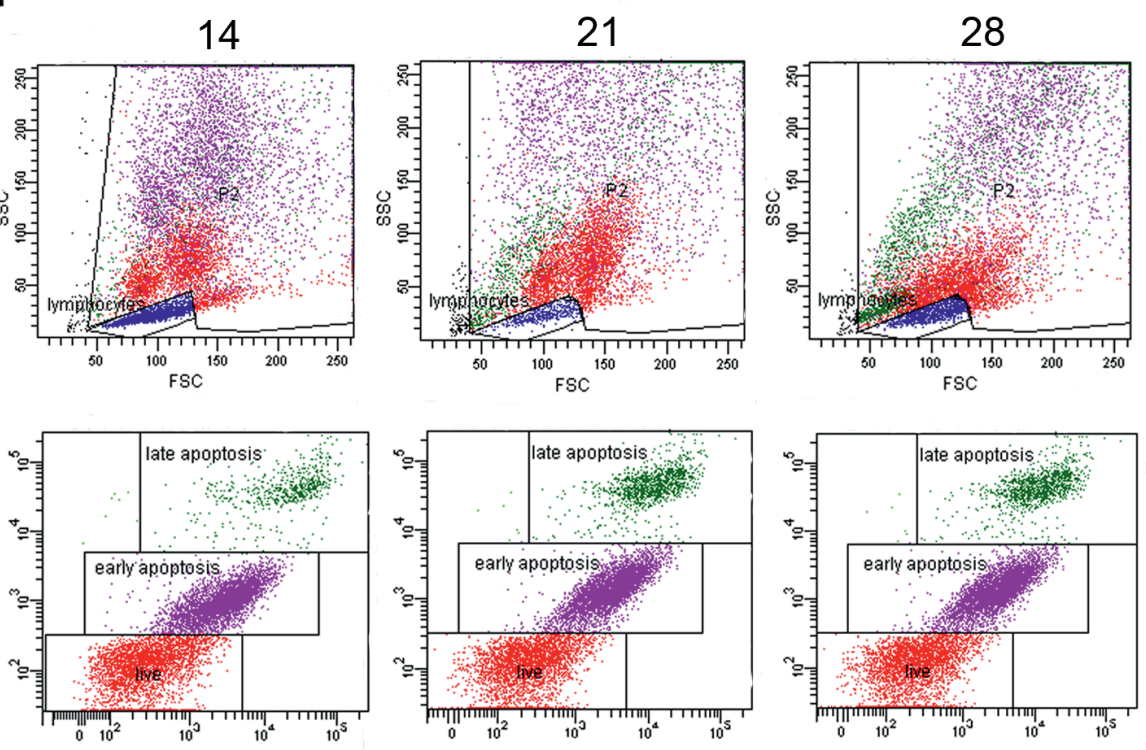

Annexin-V

Fig. 4. Myeloid cell subpopulation is more susceptible to apoptosis than lymphoid cells. Analysis of apoptosis performed using an Annexin V-FITC Apoptosis Detection Kit. (A) Gating strategy used to identify live/apoptotic cells in both lymphoid (left) or myeloid (right) subpopulations of peritoneal cells. Graph displays proportion of live, early apoptotic and late apoptotic cells $(n=4$ mice) within lymfoid $(B)$ or myeloid $(C)$ peritoneal cell subpopulations. Data are expressed as the means \pm SD. Values significantly different from healthy mice are indicated as: ${ }^{*} p<0.05,{ }^{* *} p<0.01,{ }^{* * *} p<0.001$. (D) 
al., 2006; O'Connell et al., 2009; Vendelova et al., 2015), Taenia crassiceps (Zepeda et al., 2010) and Echinococcus granulosus (Mourglia- Ettlin et al., 2011). They can persist and grow in their host for a long period of time eliciting intensive inflammatory reactions with severe pathological changes. Interestingly, proliferative metacestode stages of Mesocestoides sp. were also documented in peritoneal and pleural cavities of dogs (Toplu et al., 2004; Boyce et al., 2011) and cats (Eleni et al., 2007; Lanteri et al., 2017), although carnivores represent the definitive hosts in which tapeworm reach adult stage in the gut. There is no immunopathological restriction of parasite growth in terms of enclosing metacestodes in the fibrous capsules, thus the events occurring during the early stages of metacestode infections in peritoneum seem to be important for their establishment. The reasons why parasitic infections persist lie in the complex interactions that have evolved between parasite evasion tactics and host countermeasures. Better understanding of immunological processes and their regulation could help to design more specific and effective therapeutic intervention. In the present study, we first focussed on the kinetic changes in the proportions of lymphoid and myeloid inflammatory cells within the first month of $M$. vogae infection in susceptible ICR strain of mice. We found the massive recruitment of myeloid cells from day 7 p.i., what accounted for $68.2 \pm 3.08 \%$ from total PEC (approximately 60 million) on day 28 p.i. Although proportions of lymphoid populations declined, their total numbers elevated, but in the lesser extent than numbers of myeloid cells (data not shown). The similar massive inflammation in the peritoneal cavity of C56BL/6 mice following intraperitoneal infection with $M$. corti larvae were reported
A

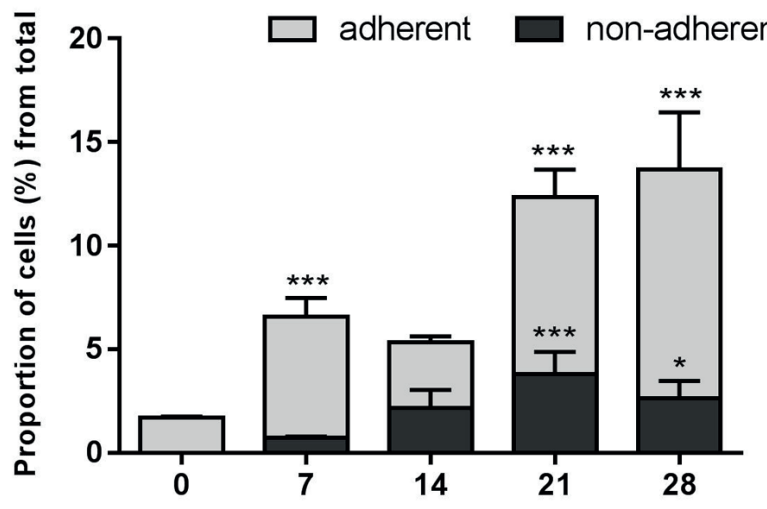

Days p.i.

C

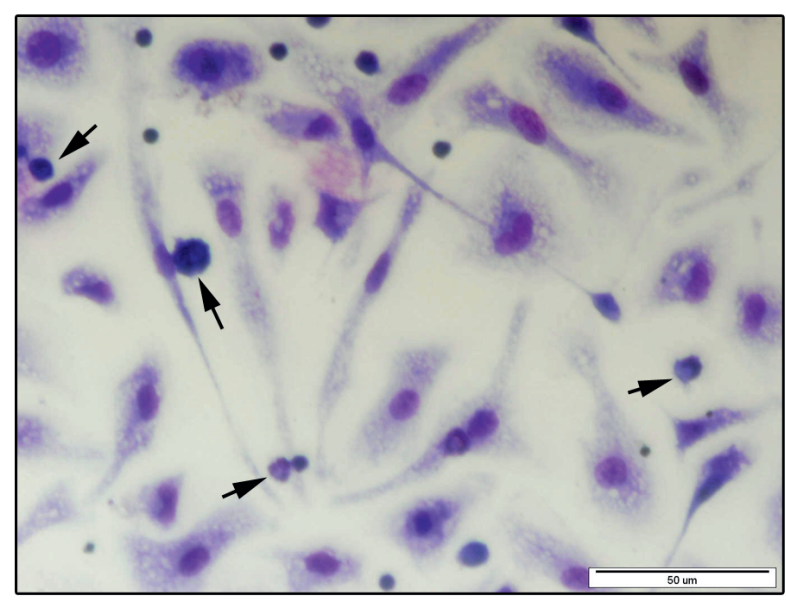

B

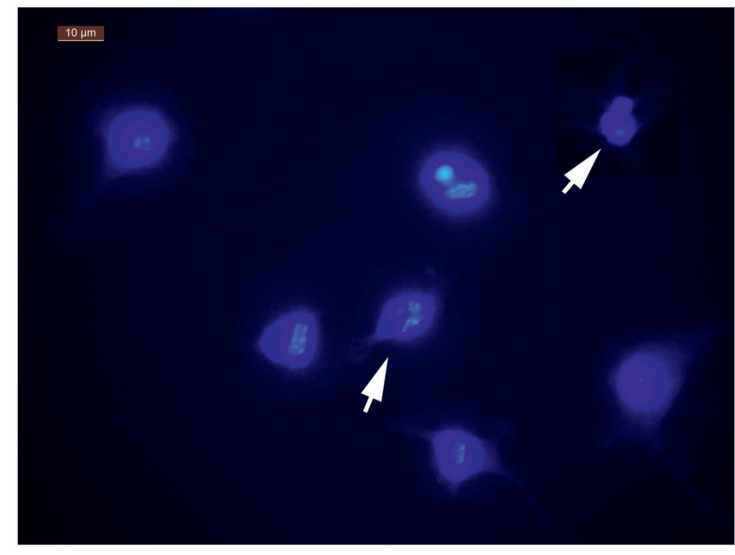

D

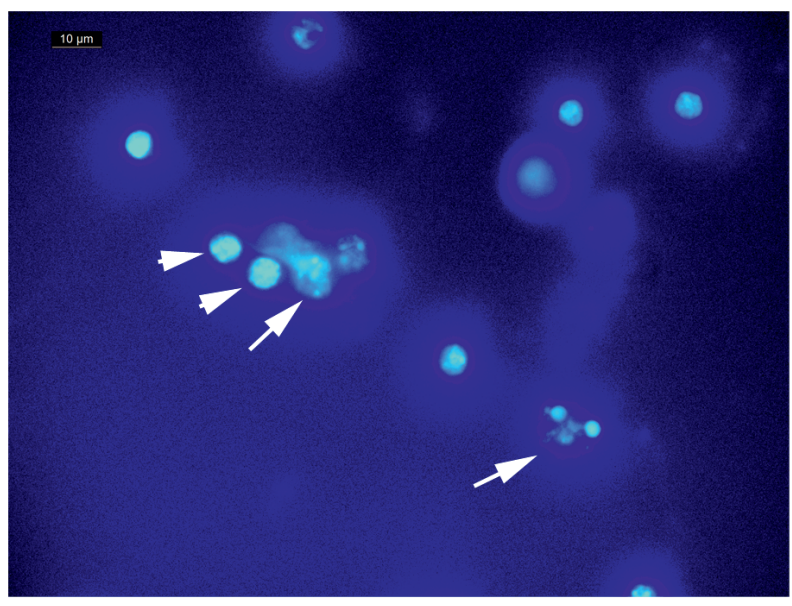

Fig. 5. Adherent fractions of myeloid peritoneal cells are more sensitive to late apoptosis in later stage of Mesocestoides vogae infection. Peritoneal cells isolated at the indicated time points, and proportions of apoptotic cell in adherent and non-adherent fraction assessed by fluorescent microscopy (A). Data are expressed as the means \pm SD. Values significantly different from healthy mice are indicated as: ${ }^{*} p<0.05,{ }^{* * *} p<0.001$. Adherent cells were stained with May-Grünwald/Giemsa solutions (C). Morphological changes of adherent cells undergoing late stage of apoptosis (arrows) and condensation of chromatin (arrowheads) were detected after staining of cell nuclei with DNA-specific dye Hoechst 33342 (B, D). 
by O'Connell et al. (2009), although this strain was shown to be the most resistant out of six inbred strains of mice (White et al., 1982). We observed several phenotypically different inflammatory myeloid cells by means of morphological evaluation and flow cytometry with increasing proportion of large granular cells, macrophage-like cells and multinucleated giant cells. In previous studies we showed that majority of these cells attained the genetic signature of alternatively activated macrophages upon direct effect of excretory/secretory (ES) larval products (Vendelova et al., 2015). These cells had dampened phagocytic ability and production of superoxide anions (Hrčková et al., 2016; Velebný et al., 2010).

$\mathrm{CD} 4+\mathrm{T}$ cell subsets have critical role in the regulation of adaptive immunity, since they provide essential help for both cytotoxic CD8+ $\mathrm{T}$ cells and humoral response. Flow cytometry analysis in our experiments revealed that the proportions of CD4+ T helper cells out of total lymphoid cells elevated up to day 14 p.i. and dropped thereafter, whereas proportions of CD8+ cells were only moderately modified. We assume that from day 14 p.i. other lymphoid populations like B cells, NK and NKT cells accounted for elevated total numbers of lymphoid cells, as we showed recently that on day 25 p.i. NK cells represented approximately $26 \%$ of lymphoid cells in PerC of ICR mice (Mačák Kubašková et al., 2018).

In the study of Mourglia-Ettlin et al. (2011) on infection with $E$. granulosus in Balb/c mice authors demonstrated that immune response in PerC elicited at early stage (by day 9 p.i.) has biphasic behavior with initial promotion of Th1 towards Th2 type. Regarding peritoneal lymphoid cells, NK cells showed a substantial increase and predominance of CD4+ cells was observed. The massive recruitment of inflammatory cells was seen after intraperitoneal infection of Balb/c mice strain with Taenia crassiceps metaces-

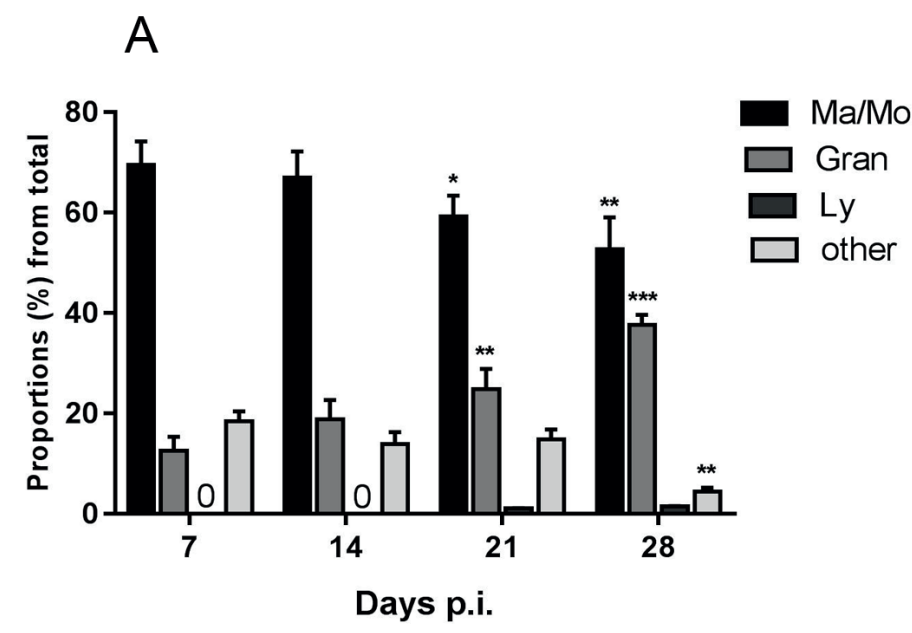

B
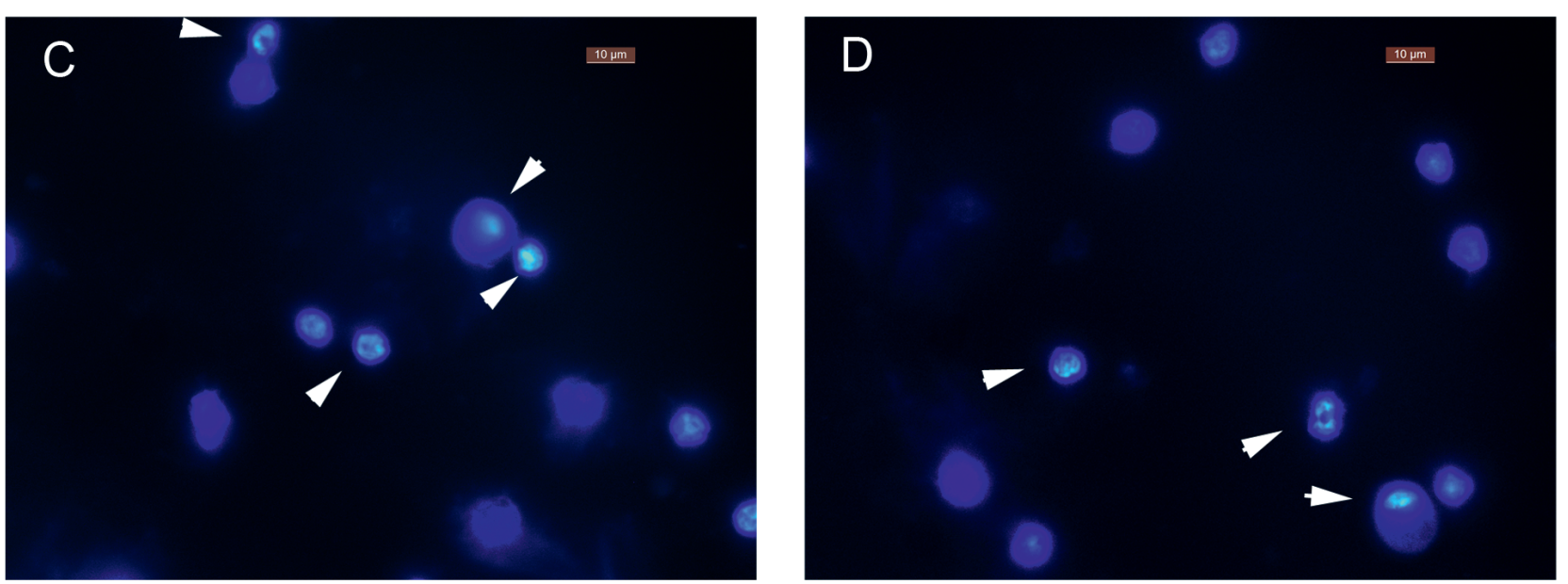

Fig. 6. Mixed populations of myeloid cells adhered to Mesocestoides vogae larval surface. Larvae isolated from peritoneal cavities of mice and incubated in complete medium for $3 \mathrm{~h}$. Then adherent cells pooled and cell smears prepared. Graph (A) depict proportion of subpopulation of adherent cells - monocyte/macrophages (Mo/ $\mathrm{Ma}$ ), granulocytes (Gran), lymphocytes (Ly) (A). Data are expressed as the means $\pm S D$. Values significantly different from healthy mice are indicated as: ${ }^{*} p<0.05$, ${ }^{* *} p<0.01,{ }^{* * *} p<0.001$. Adherent cells stained with May-Grünwald/Giemsa solutions (B). Morphological changes of cells undergoing late stage of apoptosis detected after staining of cell nuclei with DNA-specific dye Hoechst 33342 (C, D). Representative images of cell smears showing cells with condensed chromatin (arrowheads). 
todes within 16 days of examination, but the proportions of $T$ and B lymphocytes gradually decreased as detected by flow cytometry. These studies indicate that interactions between host immune system and metacestodes seem to be parasite species-specific to a certain extent.

In peritoneal cavity of healthy mice, two macrophage subsets coexist which differ from each other in the expression of surface markers CD11b, F4/80 and MHCII and only so-called small type with high expression of MHCII predominates after LPS stimulation. This population derives from blood monocytes and differentiates to mature macrophages upon stimulation (Eid Bou Ghosn et al., 2010). Transmembrane protein CD11c is also expressed on myeloid-derived cells of which mature monocytes, macrophages and granulocytes have, in general, lower expression than have mature un-stimulated dendritic cells (Lai et al., 1998). We therefore examined CD11c expression level on myeloid cells during onset of peritoneal $M$. vogae infection by flow cytometry. We found decline of cells with low expression up day 14 p.i. when population of cells with medium expression started to elevate. We suppose that on this day the shift to Th2 response occurs and CD11 $\mathrm{c}^{\text {medium }}$ cells are predominantly alternatively activated macrophages as on this time point the rapid elevation of IL-4 mRNA levels in PEC in the same model infection was found (Vendelova et al., 2015). High expression of CD11c is assigned to dendritic cells. However, Singh-Jasuja et al. (2013) showed that CD11c marker on dendritic cells is down-regulated upon cell activation through Toll-like receptor triggering. Maturation of naïve dendritic cells was shown to be impaired after exposure to ES antigens of $E$. multilocularis (Nono et al., 2012) and T. crassiceps (Terrazas et al., 2010) in vitro resulting in Th2-biasing ability. In line with these reports, Smith et al. (2011) demonstrated that CD11c ${ }^{\text {low }}$ non-plasmacytoid dendritic cell expand during chronic nematode infection inducing lower levels of antigen-specific CD4+ cells. Moreover expanded peritoneal macrophages (F4/80+phenotype) during later stage of $T$. crassiceps infection (M2 type) possessed a poor ability to induce antigen-specific proliferation of CD4+ T lymphocytes. In particular, very low proportions of $\mathrm{CD} 11 \mathrm{c}^{\text {high }}$ dendritic cells in PerC were found in our study. Collectively, we assume that highly decreased proportions of CD4+ T cells in PerC of $M$. vogae are the result of their down-regulated proliferation upon interaction with M2 macrophages and suppressive dendritic cells.

Apoptosis is highly regulated process of cell removal as opposite to necrosis and is also involved in regulation of host-parasite interactions (James \& Green, 2004). To survive within their hosts, parasitic protozoa and helminthes demonstrate the ability to modulate host apoptosis pathways to their own advantage. In our study, we showed that peritoneal lymphoid population is resistant to early apoptosis and cell death. Similar resistance of lymphocytes in PerC with $T$. crassiceps infection was reported by Zepeda et al. (2010). In contrast, substantial proportions of recruited myeloid cells occurred in early and late stage of apoptotic process from day 14 p.i. when larval proliferation is accelerated (Vendelova et al., 2015; personal observation). Assessing size and granularity of cells by flow cytometry, cells undergoing early apoptosis represented highly granular population with medium to large size, possibly immature granulocytes and macrophages. Proportions of dead cells elevated by day 28 p.i. and they were of reduced size and lower granularity. Eosinophils represent the main granulocyte population in peritoneal cavity with M. corti (Johnson et al., 1979) or $T$. crassiceps infection, and significant level of apoptosis in eosinophils in comparison with macrophages was demonstrated within 16 days p.i. (Zepeda et al. 2010). E/S products of helminthes play the role in cell-specific apoptosis what is also dependent on tissue localization of parasites. There is no information regarding the effects of $M$. vogae E/S antigens on apoptosis initiation neither in the peritoneal cavity nor in the infected liver, but this effect can be suggested based on following studies. Nono et al. (2012) showed that $E / S$ products of $E$. multilocullaris induced death of bone-marrow derived dendritic cells via apoptosis. Apoptosis of naïve rat peritoneal eosinophils was initiated by $\mathrm{E} / \mathrm{S}$ products from trematode Fasciola hepatica in vitro by caspase-dependent mechanism (Serradell et al., 2007). Adherence is basic feature of macrophages and monocytes and adherent macrophages act as scavengers of late apoptotic cells. On the other hand, non-adherent macrophages may have growth-promoting role and could rescue early apoptotic cells (Selvarajan et al., 2011). We therefore analyzed whether adherent and non-adherent PEC undergo apoptosis by assessing morphological changes of cell nuclei. Adherent cells comprised mostly monocytes and macrophages but also granulocytes (Fig. 5 B). Late apoptosis was detected in the small portion of non-adherent cells, probably granulocytes, and other types of myeloid cells as lymphoid cells were shown to be resistant to apoptosis. In the adherent cell fraction, fragmentation of cell nuclei, as definitive sign of cell death, was seen in an increased level from day 21 p.i. in correlation with flow cytometry analysis. Scavenger receptors are responsible for scavenger function of macrophages and increased expression of these receptors was demonstrated in adherent macrophages (Selvarajan et al., 2011). It is possible that $M$. vogae larval-derived E/S products induce apoptosis in selected populations of macrophages, mainly adherent fraction, and eosinophils in order to ameliorate cytotoxicity and pathology in PerC. It is well known that macrophages tend to adhere to antibody-opsonized surface of flatworms as a part of antibody-mediated cellular cytotoxicity process. In our study, populations of larvae-attached cells comprised mainly macrophages but also other cell types, including eosinophils and large granular cells with compact nuclei, possibly NK cells. Neither cell type isolated from larval surface underwent late apoptosis although condensation of nuclear chromatin in some cells indicated on the early events. Attachment of eosinophils and partially neutrophils to $M$. corti larvae in PerC of rats was reported by Cook et al. (1988) showing down-regulation of Fc receptors for antibodies on these cells, but not the complement receptors. 


\section{Conclusion}

In PerC of ICR mice M. vogae larval infection elicited the massive recruitment of inflammatory cells and their distribution changed towards accumulation of myelo-monocytic cell lineage in the account of reduced proportions of lymphoid cells. Our data demonstrated that apoptosis did not account for diminished population of peritoneal lymphoid cells, mostly CD4+T cells. Gradually elevated populations of myeloid cells with low and medium expression of CD11c became dominant cells and substantial proportions of myeloid cells were subjected to apoptotic turnover in peritoneal cavity of mice. Moreover, peritoneal adherent cells were seen in late apoptosis by contrast to cells adhered to larval surface, suggesting that cell-specific apoptosis is regulated by metacestodes to create permissive environment.

\section{Acknowledgement}

The financial support to this study was given from the Scientific Grant Agency of the Ministry of Education of Slovak Republic and the Academy of Sciences, VEGA project no. 2/0091/17 and project APVV - 17-0410.

\section{Conflict of interests}

Authors state no conflict of interest

\section{References}

Boyce, W., Shender, L., SChultz, L., VickeRs, W., Johnson, C., Ziccard, M., Beckett, L., Padgett, K., Crosbie, P., Sykes, J. (2011): Survival analysis of dogs diagnosed with canine peritoneal larval cestodiasis (Mesocestoides spp.). Vet Parasitol.,180(3-4) : 256 261. DOI: 10.1016/j.vetpar.2011.03.023

Brombacher, F., Arendse, B., Peterson, R., Hölscher, A., Hölsher, C. (2009): Analyzing classical and alternative macrophage activation in macrophage/neutrophil-specific IL-4 receptor-alpha-deficient mice. Methods Mol. Biol., 531: 225 - 252. DOI: 10.1007/9781-59745-396-7_15

Composto, G., Gonzalez, D., Bucknum, A., Silberman, D., Taylor, J., Kozlowski, M., Bloomfield, T., Bartlett, T., Riggs, J. (2011) Peritoneal T lymphocyte regulation by macrophages. Immunobiology, 216(1-2): 256 - 264. DOI: 10.1016/j.imbio.2010.04.002 COOK, R.M., Ashworth, R.F., CHernin, J. (1988): Cytotoxic activity of rat granulocytes against Mesocestoides corti. Parasite Immunol., 10(1): $97-109$

Eid Bou Ghosn, E., Cassado A.A., Govoni, G.R., Fukuhara, T., Yang, Y., Monack, D.M., Bortoluci, K.R., AlmeidA, S.R., Herzenberg, L.A., HERZENBERG, L.A. (2010): Two physically, functionally, and developmentally distinct peritoneal macrophage subsets. Proc. Natl. Acad Sci USA, 107(6): 2568 - 2573. DOI: 10.1073/pnas.0915000107. Eleni, C., Scaramozzino, P., Busi, M., Ingrosso, S., D’Amelo, S., De
LIBERATO, C. (2007): Proliferative peritoneal and pleural cestodiasis in a cat caused by metacestodes of Mesocestoides sp. Anatomohistopathological findings and genetic identification. Parasite, 14(1): 71 - 76. DOI: 10.1051/parasite/2007141071

Gordon, S., Martinez, F.O.(2010): Alternative activation of macrophages: mechanism and functions. Immunity. 32(5): 593 - 604. DOI: 10.1016/j.immuni.2010.05.007

HRČKOVÁ, G., VeleBNÝ, S. (1997): Effect of praziquantel and liposome-incorporated praziquantel on peritoneal macrophage activation in mice infected with Mesocestoides corti tetrathyridia (Cestoda). Parasitology, 114(Pt 5): $475-482$

Hrčková, G., Velebný, S., Daxnerová, Z., Solar, P. (2006): Praziquantel and liposomized glucan-treatment modulated liver fibrogenesis and mastocytosis in mice infected with Mesocestoides vogae (M. corti, Cestoda) tetrathyridia. Parasitology, 132(Pt 4): 581 - 594. DOI: 10.1017/S0031182005009364

HrČKová, G., Vendelova, E., Velebný, S. (2016): Phagocytosis in Mesocestoides vogae-induced peritoneal monocytes/macrophages via opsonin-dependent or independent pathways. Helminthologia, 53: 3 - 13. DOI: 10.1515/helmin-2015-0062

HRČKovÁ, G., VeleBnÝ, S., Kogan, G. (2017): Antibody response in mice infected with Mesocestoides vogae (syn. Mesocestoides corti) tetrathyridia after treatment with praziquantel and liposomised glucan. Parasitol. Res., 100(6): 1351 - 1359. DOI: 10.1007/ s00436-006-0434-2

HrČKovÁ, G., VelebnÝ, S., Solár, P. (2010): Dynamics of hepatic stellate cells, collagen types I and III synthesis and gene expression of selected cytokines during hepatic fibrogenesis following Mesocestoides vogae (Cestoda) infection in mice. Int. J. Parasitol., 40(2): 163 - 74. DOI: 10.1016/j.ijpara.2009.06.008

HoRSNeLL, W.G.C., BRomBACHER, F. (2010): Genes associated with alternatively activated macrophages discretely regulate helminth infection and pathogenesis in experimental mouse models. Immunobiology, 215(9-10): 704 - 708. DOI: 10.1016/j.imbio.2010.05.011 James, E.R., GreEN, D.R. (2004): Manipulation of apoptosis in the host-parasite interaction. Trends Parasitol., 20(6): 280 - 287. DOl: 10.1016/j.pt.2004.04.004

Jenkins P., Dixon, J.B., Haywood, S., Rakha, N.K., Carter, S.D., (1991): Differential regulation of murine Mesocestoides corti infection by bacterial lipopolysaccharide and interferon-gamma. Parasitology, 102: 25 - 132. DOI: 10.1017/S0031182000060431

Johnson, G.R., Nicholas, W.L., Metcalf, D., McKenzie, I.F., MitchELL, G.F. (1979): Peritoneal cell population of mice infected with Mesocestoides corti as a source of eosinophils. Int. Arch. Allergy Appl. Immunol, 59(3): 315 - 322. DOI: 10.1159/000232275

Lal, L., Alaverdi, N., Maltals, L., Morse, H.C (1998): Mouse cell surface antigens: nomenclature and immunophenotyping. J. Immunol., 160 (8): 3861 - 3868

Lanterl,G., Di Caro,G., Capucchio,M.T., Gaglio,G., Reina,V.,Lo GIUdICE, C., ZANet,S., MARINo, F. (2017): Mesocestoidosis and multivisceral tetrathyridiosis in a European cat. Veterinarni Medicina, 62: 356 - 362. DOI: 10.17221/6/2017-VETMED 
MaČÁK KubašKová, T., Mudroñová, D., VelebnÝ, S., HrČKovÁ, G. (2018): The utilisation of human dialyzable leukocyte extract (IMMODIN) as adjuvant in albendazole therapy on mouse model of larval cestode infection: Immunomodulatory and hepatoprotective effects. Int. Immunopharm., 65: 148 - 158. DOI: 10.1016/j.intimp.2018.09.045

MalzeLS, R.M. (2010): Parasite immunomodulation and polymorphisms of the immune system. J. Biol., 8(7): 62. DOI: 10.1186/ jbiol166

Maizels, R.M., Hewitson, J.P., Smith, K.A. (2012): Susceptibility and immunity to helminth parasites. Curr. Opin. Immunol., 24(4): 459 - 466. DOI: 10.1016/j.coi.2012.06.003

Martinez, F.O., Helming, L., Gordon, S. (2009): Alternative activation of macrophages: an immunologic functional perspective. Annu. Rev. Immunol., 27: 451 - 483. DOI: 10.1146/annurev.immunol.021908.132532

MourglaA-Ettlin, G., Margués, J.M., Chabalgoity, J.A., Dematteis, S. (2011): Early peritoneal immune response during Echinococcus granulosus establishment displays a biphasic behavior. PLOS Negl. Trop. Dis., 5(8):e1293. DOI: 10.1371/journal.pntd.0001293 Nono, J.K., PletincKX, K., Lutz, M.B., BREHM, K. (2012): Excretory/ secretory products of Echinococcus multilocularis larvae induce apoptosis and tolerogenic properties in dendritic cells in vitro. PloS Negl. Trop. Dis., 6, e1516. DOI: 10.1371/journal.pntd.0001516 O'Connel, A.E., Kerepesi, L.A., Vandergrift, G.L., Herbert, D.R., Van Winkle, T.J., Hooper, D.C., Pearce, E.J., Abraham, D. (2009): IL-4(-/-) mice with lethal Mesocestoides corti infections-reduced Th2 cytokines and alternatively activated macrophages. Parasite Immunol. 31: 741 - 749. DOI: 10.1111/j.1365-3024.2009.01151.x Rawat, J., Dixon, J.B., Macintyre, A.R., McGarry, H.F., Taylor, M.J. (2003): IL-4 dependent resistance to the tapeworm Mesocestoides corti (Cestoda) in mice. Parasite Immunol., 25(11-12): 553 - 557. DOI: $10.1111 / \mathrm{j} .0141-9838.2004 .00666 . x$

Rodriguez-Sosa, M., Satoskar, A.R., Calderón, R., Gomez-Garcia, L., Saavedra, R., Bojall, R., Terrazas, L.I. (2002): Chronic helminth infection induces alternatively activated macrophages expressing high levels of CCR5 with low interleukin-12 production and Th2-biasing ability. Infect. Immun., 70(7): 3656 - 3664. DOI: 10.1128/IAI.70.7.3656-3664.2002

Selvarajan, K., Moldovan, L., Chandrakala, A.N., Litvinov, D., Parthasarathy, S. (2011): Peritoneal macrophages are distinct from monocytes and adherent macrophages. Atherosclerosis, 219(2): 475-83. DOI: 10.1016/j.atherosclerosis.2011.09.014

Serradell, M.C., Guasconi, L., Cervi, L., Chiapello, L.S., Masih, D.T. (2007): Excretory-secretory products from Fasciola hepatica induce eosinophil apoptosis by a caspase-dependent mechanism. Vet. Immunol. Immunopathol., 117: 197 - 208. DOI: 10.1016/j.vetimm.2007.03.007

Singh-Jasuja, H., Thiolat, A., Ribon, M., BoIssier, M.C., Bessis, N., Rammensee, H.G., DeCKer, P. (2013): The mouse dendritic cell marker CD11c is down-regulated upon cell activation through Toll-like receptor triggering. Immunobiology, 218(1): 28 - 39. DOI: 10.1016/j.imbio.2012.01.021
Smith, K.A., Hochweller, K., Hämmerling, G.J., Boon, L., MacDonALD, A.S., Malzels, R.M. (2011): Chronic helminth infection promotes immune reagulation in vivo through dominance of $\mathrm{CD} 11 \mathrm{C}^{\mathrm{i}}$ ${ }^{\circ}$ CD103-dendritic cells. J. Immunol., 168(12): 7098 - 7109. DOI: 10.4049/jimmunol.1003636

Solano, S., Cortes, I. M., Copitin, N.I., Tato, P., Molinari, J.L. (2006): Lymphocyte apoptosis in the inflammatory reaction around Taenia solium metacestode in porcine cysticercosis. Vet. Parasitol. 140: 171 - 176. DOI:10.1016/j.vetpar.2006.03.006

SPECHT, D., Voge, M. (1965): Asexual multiplication of Mesocestoides tetrarhyridia in laboratory animals. J. Parasitol. 51(2): 268 $-272$

SPECHT, D., WIDMER, E.A. (1972): Response of mouse liver to infection with tetrathyridia of Mesocestoides (Cestoda). J. Parasitol., 58(3): 431 - 437. DOI: 10.2307/3278183

Spotin, A., Mokhtari, M., Majdi, A., Sankian, M., Varasteh, A. (2012): The study of apoptotic bifunctional effects in relationship between host and parasite in cystic echinococcosis: a new approach to suppression and survival of hydatid cyst. Parasitol. Res. 110(5): 1979 - 1984. DOI: 10.1007/s00436-011-2726-4.

Terrazas, C.A., Gómez-Garcia, L., TerrazAs, L.I. (2010): Impaired pro-inflammatory cytokine production and increased Th2-biasing ability of dendritic cells exposed to Taenia excreted/secreted antigens: A critical role for carbohydrates but not for STAT6 signaling. Int.J. Parasitol., 40(9): 1051 - 1062. DOI: 10.1016/j.ijpara.2010.02.016.

Toplu, N., YILDIZ, K., TUnAY, R. (2004): Massive cystic tetrathyridiosis in a dog. J. Small Anim. Pract., 45(8): 410 - 412. DOl: 10.1111/j.1748-5827.2004.tb00257.x.

VelebnÝ, S., HrČKova, G., KönIGová, A., (2010). Reduction of oxidative stress and liver injury following silymarin and praziquantel treatment in mice with Mesocestoides vogae (Cestoda) infection. Parasitol. Int., 59: 524 - 531. DOI:10.1016/j.parint.2010.06.012

Vendelova, E., LUTZ, M.B., HRČKovÁ, G. (2015): Immunity and immune modulation elicited by the larval cestode Mesocestoides vogae and its products. Parasite Immunol. 37: 493 - 504. DOI: 10.1111/pim.12216

Vendelova, E., HrčKová, G., Lutz, M.B., Brehm, K., Nono Komguep, J. (2016a): In vitro culture of Mesocestoides corti metacestodes and isolation of immunomodulatory excretory-secretory products. Parasite Immunol., 38(7): 403 - 413. DOI: 10.1111/pim.12327

Vendelova, E., Camargo de, L.J., Lorenzatto, K.R., Monteiro, K.M., Mueller, T., Veepaschit, J., Grimm, C., Brehm, K., HrČKová, G., Lutz, M.B., Ferreira, H.B., Nono, K.J. (2016b): Proteomic analysis of excretory-secretory products of Mesocestoides corti metacestodes reveals potential suppressors of dendritic cell functions. PLoS Negl. Trop. Dis. 10(10): e0005061. DOI: 10.1371/journal. pntd.0005061

VoeHRINGer, D., ShinKAI, K., LOCKSLEY, R.m. (2004): Type 2 immunity reflects orchestrated recruitment of cells committed to IL-4 production. Immunity. 20(3): 267 - 277. DOI: 10.1016/S10747613(04)00026-3 
Vuitton, A., Gottstein, B. (2010): Echinococcus multilocularis and its intermediate host: a model of parasite-host interplay. J. Biomed. Biotechnol., 2010: ID923193. DOI: 10.1155/2010/923193.

White, T.R., Thompson, R.C.A., Penhale, W.J. (1982): A comparative study of the susceptibility of inbred-strains of mice to infection with Mesocestoides corti. Int. J. Parasitol., 12(1): 29 - 33. DOI: 10.1016/0020-7519(82)90091-1
Wyllie, P.J. (1997): Apoptosis: An overview. Brit. Med. Bull., 53(3): 451 - 465. DOI: 10.1093/oxfordjournals.bmb.a011623

Zepeda, N., Solano, S., Copini, N., Fernández, A.M., Hernández, L., TATO, P., MolinarI, J.L. (2010): Decrease of peritoneal inflammatory $\mathrm{CD}^{+}, \mathrm{CD}^{+}, \mathrm{CD} 19^{+}$lymphocytes and apoptosis of eosinophils in a murine Taenia crassiceps infection. Parasitol. Res., 107(5): 1129 - 1135. DOI: 10.1007/s00436-010-1980-1 